\title{
Tendrils as an Alternate Tissue Source for Chromosome Visualization
}

\author{
R.C. Yadav and Rebecca Grumet ${ }^{1}$ \\ Department of Horticulture, Michigan State University, East Lansing, MI 48824
}

Additional index words. melon, cucumber, pea, grape, tetraploidy, transformation, cytogenetics

\begin{abstract}
Tendrils were used as an alternate tissue source to determine the ploidy level of transgenic melon (Cucumis melo L.) plants. Young tendril tips were prepared for chromosome visualization using standard root tip preparation techniques. Well-spread chromosome preparations were obtained. Tendrils were found to be as amenable to chromosome visualization as root tips. The transformed melon plants, representing three transgenic melon lines, were tetraploid. The tendril technique also was applied successfully to several other tendril-producing species: cucumber (C. sativus $\mathbf{L}$.), pea (Pisum sativum L.), and grape (Vitis vinifera $\mathbf{L}$.). This technique can be very useful for chromosome visualization in tendrilproducing species, and can be especially valuable when root tips or anthers cannot be obtained easily.
\end{abstract}

Cytological studies of plants have generally relied on the use of root tips or anthers as a tissue source for chromosome visualization. Although these are excellent sources for such studies, they are not always available; plants are not in constant bloom, and root tips are not always accessible. In an effort to determine the ploidy level of transgenic melon plants, we sought an alternate tissue source for chromosome visualization. Melons and several other vining species produce a specialized organ, the tendril, which is located above ground, is present in vegetative plants, and may prove suitable for cytological purposes.

Tendrils are cylindrically shaped, coiling structures that provide physical support in several species of climbing or vining plants (Putz and Holbrook, 1991). These structures are not equivalent morphologically in all taxa. A tendril may be a modification of a branch or foliar leaf (Cucurbitaceae; Lawrence, 1951), leaflet (Fabaceae; Bailey, 1949), shoot apex (Vitaceae; Lawrence, 1951) or terminal flower (Passifloraceae; Lawrence, 1951). Tendrils are green growing tissues that are thigmotropically responsive until they fully elongate (Jaffe and Galston, 1968). In this report we demonstrate that tendrils of species representing several taxa are an excellent tissue source for cytological work. Chromosomes were readily visualized from tendrils of melon and cucumber [Cucumis melo L. and C. sativus L., respectively (Cucurbitaceae)], pea [Pisum sativum L. (Leguminaceae)], and grape [Vitis vinifera L. (Vitaceae)].

\section{Materials and Methods}

Young tendril tips were collected from greenhouse-grown pea plants ('Alaska'; Ferry Morse Seed, Fulton, Ky.), grape vines ('Couderc'; gift of Donald Ramsdell, Michigan State Univ., East Lansing), cucumber plants ('TMG-1'; Provvidenti, 1987), and transgenic (Fang and Grumet, 1993) and nontransgenic melon plants ('Hale's Best Jumbo'; Asgrow Seed Co., Kalamazoo, Mich.). Chromosome preparation methods were adapted from

Received for publication 28 May 1993. Accepted for publication 2 Dec. 1993. We thank Jae Min Lee for assistance with maintaining transgenic melon plants and producing rooted cuttings and Joanne Whallon and Jim Hancock for critical reviews of the manuscript. This work was supported in part by Cooperative Agreement 263-01520A-00-306-00 of the U.S. Agency for International Development and by the Michigan Agricultural Experiment Station. The cost of publishing this paper was defrayed in part by the payment of page charges. Under postal regulations, this paper therefore must be hereby marked advertisement solely to indicate this fact.

${ }^{1}$ To whom reprint requests shouls be addressed. those used commonly for roots. Tendril tips were fixed in Farmer's fluid (1 glacial acetic acid : 3 ethanol, Sharma and Sharma, 1980) or Carnoy's fluid (1 glacial acetic acid : 3 chloroform : 6 ethanol, Sharma and Sharma, 1980) for $24 \mathrm{~h}$ at $4 \mathrm{C}$, then washed with distilled water to remove all fixative and hydrolyzed in $1 \mathrm{M} \mathrm{HCl}$ for $10 \mathrm{~min}$ at $60 \mathrm{C}$. The $\mathrm{HCl}$ was removed by soaking the tips in distilled water for $15 \mathrm{~min}$. Meristematic tips (2-to 3-mm segments) were placed on a slide in a drop of acetocarmine $[0.5 \%$ carmine (Sigma Chemical Co., St. Louis) in $45 \%$ acetic acid]. The slide was slightly warmed and tapped gently, but thoroughly, with a glass rod or dissecting needle to macerate the tissue before applying the cover slip. Metaphase spreads of ten cells from each of five plants per species were analyzed to establish or confirm chromosome number. For structural comparisons, meristematic regions of tendril and root tips of cucumber were hydrolyzed in $1 \mathrm{M} \mathrm{HCl}$ for 10 min at 60C, washed in distilled water, and gently pressed before viewing by light microscopy.

\section{Results and Discussion}

Young tendrils were found to have a growing tip with an actively dividing meristematic region (Fig. 1). However, when tendril tips were compared to root tips, there were several differences. First, there is no tendril cap comparable to the root cap. Second, although the meristematic region of a root tip, which is noted for its greyish color, can be seen with the naked eye, the meristematic region of the tendril tip was not readily seen, even after fixation, without a microscope. The dividing zone of the tendril tip first was identified by sequentially scanning 2 - to $3-\mathrm{mm}$ segments for occurrence of metaphase cells. The meristematic zone was located in the first $2 \mathrm{~mm}$ from the tip. Although vascular tissue runs nearly the full length of the tendril, it did not interfere with cytological analysis.

Quality of the chromosome preparations was comparable regardless of whether tendrils (Fig. 2A) or roots (Fig. 2B) were used. Fixation of tendrils with either Farmer's or Carnoy's fluids worked equally well. Chlorophyll was successfully removed at the fixation step; any starch grains present in the meristematic cells were removed by the hydrolysis and warming treatments. To obtain clear preparations of the chromosomes, it was essential to use young, actively growing tendrils ( 2 to $5 \mathrm{~cm}$ in length).

Transgenic melons transformed with various versions of the zucchini yellow mosaic virus coat protein gene (Fang and Grumet, 1993) were examined for ploidy level using the tendril method. Transgenic plants from lines CP 401, 207, and AS 221 were found 

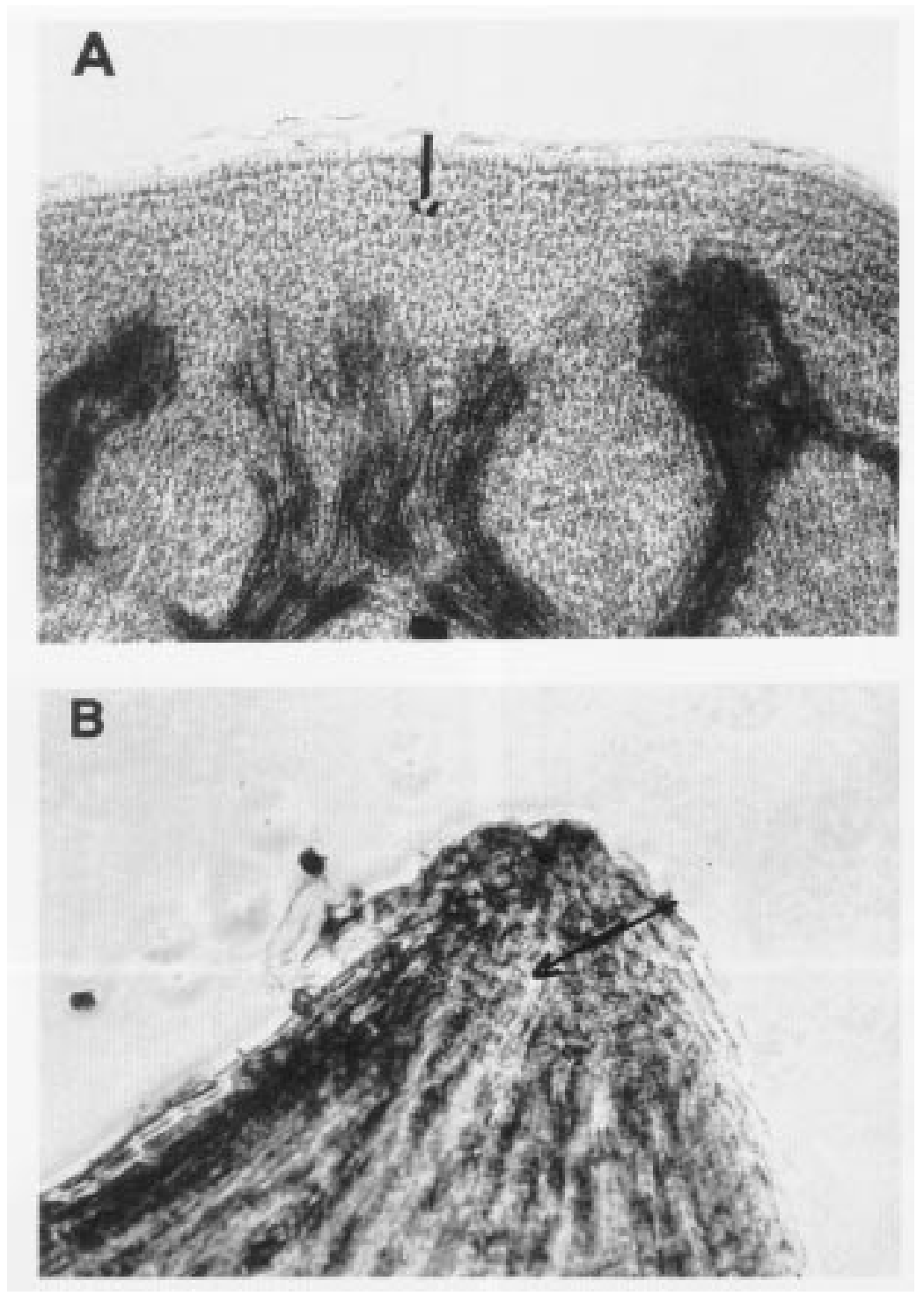

Fig. 1. Photomicrographs of tendril tips (A) and root tips $(\mathbf{B})$ of cucumber. Arrows indicate meristematic zones. Magnification $=\times 200$.

to have 48 chromosomes, indicating that tetraploid plants had been regenerated [line $\mathrm{CP} 401$ shown in Fig. 2, A and B; nontransgenic, diploid melon $(2 \mathrm{n}=24)$, Fig. $2 \mathrm{C}]$. A high frequency of tetraploidy was reported recently for melon plants regenerated from tissue culture ('Gulfstream', 'Charantais', 'Prince', 'Andel', and 'Amus'; Ezura et al., 1992; Fassuloitis and Nelson, 1992). This report extends observation of tetraploidy in regenerated melons to transgenic plants and to an additional cultivar (Hale's Best Jumbo).

Well-separated chromosomes also were observed readily from the tendril tips of cucumber, pea, and grape (Fig. 2, D-F). As expected, the number of chromosomes observed was the same as reported earlier for each species based on root tip analyses (Bennett and Smith, 1991): cucumber, 2n = 14 (Fig. 2E); pea 2n = 14 (Fig. 2D); grape, $2 \mathrm{n}=38$ (Fig. 2F; Nebel, 1929).

These results demonstrate that young, actively growing tendrils can be an excellent tissue source for chromosome visualization. Although tendrils are modifications of different tissues in various taxa, all have a growing tip composed of actively dividing, meristematic tissue. Cytological investigations were performed by Kato et al. (1984) to determine the plane of cell division in the tendril of a achlorophyllous root parasite, Aeginetia indica L. . However, to the best of our knowledge, tendrils have not been utilized previously for chromosome visualization. Despite their limited distri- bution in the plant kingdom, (tendril-producing species are found in ten plant families: Asteraceae, Bignoniaceae, Cucurbitaceae, Fabaceae, Fumariaceae, Liliaceae, Passifloraceae,Polemoniaceae, Sapindaceae, and Vitaceae; Jaffe and Galston, 1968), for those species that produce them, tendrils may be highly useful structures for cytological studies. Tendrils may be particularly valuable in situations when root tips or anthers are not obtained easily.

\section{Literature Cited}

Bailey, L.H. 1949. Manual of cultivated plants. Macmillan, New York. Bennett, M.D. and J.B. Smith. 1991. Nuclear DNA amounts in angiosperms. Philosophical Transactions of the Royal Soc. Lond. Ser. B. 334:309-345.

Ezura, H., H. Amagai, D. Yoshioka, and K. Oosawa. 1992. Highly frequent appearance of tetraploidy in regenerated plants, a universal phenomenon in tissue cultures of melon (Cucumis melo). Plant Sci. 85:209-213.

Fang, G. and R. Grumet. 1993. Genetic engineering of potyvirus resistance using constructs derived from the zucchini yellow mosaic virus coat protein gene. Mol. Plant-Microbe Interactions 6:358-367.

Fassuloitis, G. and B.V. Nelson. 1992. Regeneration of tetraploid muskmelons from cotyledons and their morphological differences from two diploid muskmelon genotypes. J. Amer. Soc. Hort. Sci. 117:863-866. Jaffe, M.J. and A.W. Galston. 1968. The physiology of tendrils. Annu. 

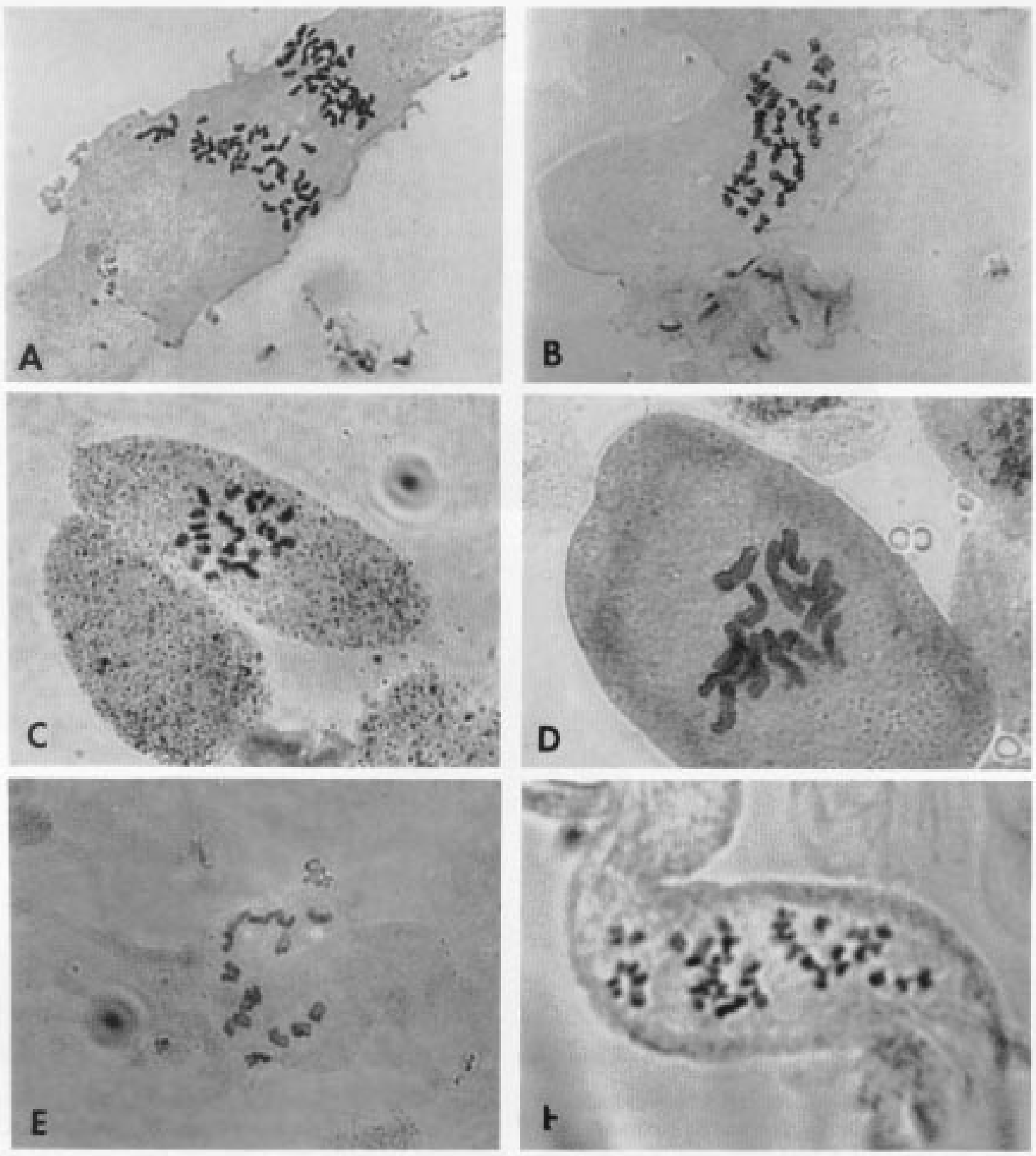

Fig. 2. Photomicrographs of mitotic metaphase chromosomes prepared from tendril and root tips of muskmelon, and from tendril tips of cucumber, pea, and grape. Magnification $=\times 1000$. A. Tendril-tip preparation from a tetraploid, transgenic melon plant $($ line 401$) ; 4 n=48$. B. Root tip preparation from a tetraploid transgenic melon plant (line 401); $4 \mathrm{n}=48$. C. Tendril-tip preparation from a nontransgenic, diploid melon; $2 \mathrm{n}=24$. D. Tendril tip preparation from pea; $2 \mathrm{n}=14$. E. Tendril tip preparation from cucumber; $2 \mathrm{n}=14$. F. Tendril tip preparation from grape; $2 \mathrm{n}=38$.

Rev. Plant Physiol. 19:417-434.

Kato, Y., T. Inoue, and Y. Onishi. 1984. In vitro culture of a root parasite, Aeginetica indica L. Plant Cell Physiol. 25:981-987.

Lawrence, G.H.M. 1951. Taxonomy of vascular plants. Macmillan, New York.

Nebel, B.R. 1929. Chromosome counts in Vitis and Pyrus. Amer. Naturalist 63:188-189.
Provvidenti, R. 1987. Inheritance of resistance to a strain of zucchini yellow mosaic virus in cucumber. HortScience 22:102-103.

Putz, F.E. and N.M. Holbrook. 1991. Biomechanical studies of vines, p. 73-97. In: F.E. Putz and H.A. Mooney (eds.). The biology of vines. Cambridge Univ. Press, New York.

Sharma, A.K. and A. Sharma. 1980. Chromosome techniques: theory and practice. Butterworth, Boston. 